\title{
UPAYA PENINGKATAN MINAT DAN HASIL BELAJAR FISIKA SISWA KELAS XII.IPA.3 SMAN 3 MUARO JAMBI MELALUI MEDIA PEMBELAJARAN ANIMASI 3 DIMENSI TAHUN PELAJARAN 2018/2019
}

\author{
SYAEMAR LIZA \\ SMA Negeri 3 Muaro Jambi Provinsi Jambi \\ anis.liza@yahoo.com
}

\begin{abstract}
ABSTRAK
Tujuan penelitian ini adalah untuk meningkatkan minat dan hasil belajar fisika menggunakan media pembelajaran animasi 3 dimensi untuk siswa kelas XII.IPA.3 SMA Negeri 3 Muaro Jambi Provinsi Jambi semester genap tahun pelajaran 2018/2019. Keberhasilan penelitian ditentukan bahwa apabila minat siswa terhadap pelajaran fisika secara klasikal sangat tinggi, dan ketuntasan hasil belajar fisika secara klasikal mencapai sekurang-kurangnya $85 \%$ dari seluruh siswa. Penelitian ini dilakukan sesuai dengan tahapan penelitian tindakan kelas, subyek penelitian 35 siswa yang terdiri atas 15 siswa laki-laki dan 20 siswa perempuan. Teknik pengambilan data yaitu angket minat belajar fisika dan tes hasil belajar, dengan analisis prensentase. Hasil penelitian diperoleh yaitu minat belajar fisika pra siklus $65 \%$ kategori cukup tinggi, siklus I 79\% kategori tinggi, dan siklus II 81\% kategori sangat tinggi. Sedangkan hasil belajar diperoleh ketuntasan klasikal pra siklus 11\%, siklus I 20\%, dan siklus II 89\%. Berdasarkan hasil ini baik minat maupun hasil belajar mengalami peningkatan bahkan mencapai indikator keberhasilan.
\end{abstract}

Kata Kunci:minat belajar, hasil belajar, fisika, media pembelajaran 3 dimensi

\section{PENDAHULUAN}

Pendidikan menengah bertujuan meningkatkan pengetahuan, kecerdasan, pengetahuan, akhlak mulia, kepribadian, serta keterampilan untuk mandiri dan mengikuti perkembangan teknologi (Yuda, dkk, 2014). Pendidikan memiliki peran yang sangat penting karena dapat meningkatkan kualitas hidup manusia dan dapat mengembangkan potensinya, sehingga dapat memenuhi kebutuhan hidupnya sendiri (Diani, 2016).

Dinamika dunia pendidikan yang sangat beragam, tentu saja memiliki dampak terhadap kualitas belajar siswa di sekolah. Dalam hal ini beberapa faktor dominan yang mempengaruhi kualitas belajar siswa diantaranya yaitu faktor yang berasal dari dalam diri siswa (faktor internal) dan faktor yang berasal dari luar (faktor eksternal). Hal ini berlaku bagi seluruh warga sekolah yang terdiri dari kepala sekolah, guru dan siswa. Faktor internal diantaranya adalah minat, bakat, motivasi, dan tingkat intelegensi. Sedangkan faktor eksternal diantaranya adalah faktor media pembelajaran, media, strategi dan lingkungan. Salah satu faktor penting dari dalam diri siswa inilah yang menentukan berhasil tidaknya siswa dalam proses pembelajaran, yaitu minat belajar.

Pembelajaran fisika memiliki tujuan diantaranya mengembangkan pengetahuan, pemahaman, dan kemampuan analisis siswa terhadap lingkungan dan sekitarnya. Mims dalam Aizah, dkk (2015) menjelaskan bahwa Pembelajaran fisika pada siswa diharapkan tidak hanya untuk menguasai konsep tetapi juga menerapkan konsep yang telah mereka pahami dalam penyelesaian masalah fisika. Namun, pembelajaran dalam kelas cenderung menekankan pada penguasaan konsep dan mengesampingkan kemampuan mengantarkan siswa menguasai konsep-konsep Fisika dan keterkaitannya untuk memecahkan masalah-masalah yang terkait dalam kehidupan sehari-hari. Artinya,bahwa pendidikan fisika harus menjadikan siswa tidak sekedar tahu (to know) dan hafal (to memorize) tentang konsep-konsep fisika saja, melainkan harus menjadikan siswa untuk mengerti dan menguasai dan memahami (to understand) konsepkonsep tersebut dan menghubungkan suatu konsep dengan konsep lain (Aji, dkk, 2017). Akan tetapi sebagian siswa merasa kesulitan dalam mempelajari fisika, hal ini disebabkan karena 
fisika lebih memerlukan pemahaman daripada penghafalan dan kebanyakan siswa merasa kesulitan terhadap teori serta terjebak dalam pemahaman rumus.Sehingga mengurangi ketertarikan serta kesadaran terhadap pentingnya ilmu fisika dalam kehidupan sehari-hari nantinya. Jika minat atau ketertarikan siswa terhadap fisika mulai berkurang, maka motivasi untuk mempelajarinya pun akan berkurang.Pembelajaran IPA khususnya fisika tidak hanya terbatas pada belajar fakta, konsep, prinsip, hukum, tetapi juga belajar tentang cara memperoleh informasi, penerapan teknologi, bekerja secara ilmiah, dan kemampuan berpikir (Pistanty dkk, 2015).

Fisika merupakan salah satu cabang IPA yang mempelajari benda-benda di alam secara fisik dan dituliskan secara matematis agar dapat dimengerti oleh manusia dan dimanfaatkan untuk kesejahteraan umat manusia (Sujanem, 2012). Berdasarkan hal tersebut maka pembelajaran fisika tidak lepas dari penguasaan konsep, menerapkannya dalam penyelesaian masalah fisika, dan bekerja secara ilmiah. Namun, pembelajaran fisika dalam kelas saat ini cenderung menekankan pada penguasaan konsep dan mengesampingkan kemampuan pemecahan masalah fisikasiswa sehingga kemampuan siswa dalam memecahkan permasalahanmasih tergolong rendah (Hudha dkk, 2017). Begitu kompleks dan rumitnya pelajaran fisika tersebut, maka di butuhkan bentuk inovasi yang lebih mumpuni dalam menjawab tantangan pembelajaran fisika (Anggraeni, dkk, 2013).

Di sisi lain, pesatnya kemajuan teknologi dan komunikasi serta tingginya dinamika dunia pendidikan terlebih di bidang fisika, menuntut penggunaan media dalam proses pembelajaran, dimana alasannya adalah sebagai penarik minat siswa terhadap mata pelajaran tersebut. Diantara sekian banyak media yang digunakan, salah satunya adalah penggunaan program media pembelajaran 3 dimensi. Karena selain sebagai media pembelajaran, program ini juga menyediakan berbagai keunggulan dalam hal pengalaman menarik bermain animasi 3 dimensi. Sehingga dari program ini dapat dikembangkan bahan ajar fisika (Physics Courseware) sebagai upaya meningkatkan pemahaman, ketertarikan dan minat siswa terhadap pelajaran fisika.

Fisika pada kenyataannya menjadi salah satu mata pelajaran yang dianggap berat dan dihindari oleh sebagian siswakarena membutuhkan ketekunan, keseriusan dan banyak latihan. Fisika masih dianggap sulit bagi siswa terutama karena pembelajaran berlangsung secara konvensional dimana siswa diharuskan menghafalkan rumus-rumus yang abstrak. Minat belajar fisika siswa yang rendah menyebabkan siswa malas mengerjakan tugas, kurang suka membaca buku atau hal-hal yang berkenaan dengan fisika, dan merasa senang bila tidak belajar fisika karena guru tidak hadir. Hal ini akan mengganggu proses belajar siswa dan membuat tujuan pembelajaran tidak tercapai. Akibatnya, kualitas pendidikan menurun karena rendahnya hasil belajar siswa. Untuk itu perlu diadakan penilaian terhadap aspek belajar siswa (Astalini, 2018).

Berdasarkan observasi dan wawancara, salah satu faktor penyebab yang paling menonjol kurangnya minat belajar siswa kelas XII.MIPA.3 SMA Negeri 3 Muaro Jambi pada mata pelajaran fisika adalah anggapan bahwa begitu banyaknya rumus dan fakta-fakta yang harus dihafal sehingga terkesan rumit dan membosankan. Pembelajaran sebelumnya guru sebagai penyaji materi, sedangkan siswa sebagai pendengar. Artinya rata-rata guru menggunakan media konvensional dalam pembelajaran di kelas, sehingga menyebabkan siswa kurang aktif. Kekurangaktifan siswa inilah yang biasanya menjadi pemicu rendahnya minat belajar dan akan berdampak pada hasil belajar fisika. Kurangnya inovasi dan kreatifitas guru akan menjadi penghambat tercapainya pembelajaran yang efektif bagi pembelajaran fisika. Pengembangan media berbasis teknologi seperti animasi bagi pelajaran fisika akan berdampak sangat signifikan dalam memberikan pengalaman baru bagi siswa sehingga siswa mampu memahami materi dalam pelajaran fisika secara utuh (Wiyoko, 2014).

Berdasarkan hasil ulangan yang diperoleh dari pembelajaran sebelumnya (pra siklus) nilai rata-rata fisika kelas XII.MIPA.3 adalah 45,0 dengan penjabaran sebagai berikut; dari 35 siswa siswa tuntas hanya 4 orang sedangkan yang tidak mencapai ketuntasan 31 orang, kalau dipersentase hanya $11 \%$ yang mencapai nilai ketuntasan. 
Dalam pendidikan, teknologi harus digunakan dengan tepat agar dapat meningkatkan kualitas belajar yang dialami siswa (Syahrowardi, dkk, 2016). Perkembangan teknologi ditandai dengan munculnya berbagai kegiatan berbasis teknologi, seperti e-commerce, $e$ government, e-medicine, e-laboratory, serta e-education, yang semuanya berbasis teknologi elektronik. Dalam pembelajaran, perkembangan teknologi dapat dirasakan terutama pada bahan ajar, salah satunya adalah media pembelajaran animasi 3 dimensi. Pengembangan dan inovasi di bidang pendidikan telah berkembang di banyak negara maju. Hal ini terbukti dari banyaknya aplikasi atau software baru yang hadir untuk membantu berjalannya proses belajar mengajar seperti animasi dalam bentuk flash maupun html, ataupun simulasi seperti phet (Kurniawati, 2016).

Penerapan media pembelajaran 3 dimensi merupakan salah satu sarana untuk mempermudah penyampaian materi dari guru kepada siswa. Dengan penerapan media pembelajaran 3 dimensi akan memberikan paradigma bahwa guru atau instruktur bukanlah satu-satunya sumber belajar. Guru hanya sebatas memfasilitasi pembelajaran di dalam kelasnya. Selain itu penerapan media 3 dimensi diharapkan dapat meningkatkan kualitas proses pembelajaran. Media pembelajaran 3 dimensi memberikan ruang bagi siswa untuk meningkatkan aktivitas dan kreativitas untuk mencari informasi terkait dengan materi yang disampaikan. Disamping itu dengan media pembelajaran 3 dimensi siswa dapat memanfaatkan animasi sebagai media pembelajaran. Dengan media yang digunakan dapat membantu siswa cepat memahami materi Fisika yang disampaikan.

Berdasarkan latar belakang masalah diatas, maka penelitian ini bertujuan untuk meningkatkan minat dan hasil belajar fisika pada kelas XII.MIPA.3 SMA Negeri 3 Muaro Jambi dengan pendekatan media pembelajaran animasi 3 dimensi. Penelitian ini dikatakan berhasil apabila minat siswa terhadap pelajaran fisika secara klasikal sangat tinggi, dan ketuntasan hasil belajar fisika secara klasikal mencapai sekurang- kurangnya $\mathbf{8 5} \%$ dari seluruh siswa.

\section{METODE PENELITIAN}

Penelitian ini merupakan Penelitian Tindakan Kelas (PTK) atau sering disebut dengan istilah dalam bahasa Inggris Classroom Action Research. Ruang lingkup penelitian pada aspek minat siswa pada mata pelajaran fisika sekaligus aspek hasil belajar fisika. Dengan penerapan media pembelajaran 3 dimensi dimaksudkan untuk meningkatkan minat dan hasil belajar fisika.

Subyek dari penelitian tindakan kelas ini adalah siswa kelas XII.MIPA.3 SMA Negeri 3 Muaro Jambi yang berjumlah 35 siswa, terdiri atas 15 siswa laki-laki dan 20 siswa perempuan.Penelitian ini dilakukan sebanyak 2 siklus yaitu siklus I dan siklus II. Kedua siklus tersebut menerapkan pendekatan metode presentasi kolaborasi dengan metode diskusi. Materi yang diajarkan yaitu siklus I, Radiasi Benda Hitam dan Teori Atom, sedangkan siklus II, Fisika Inti dan Radioaktifitas. Penelitian tindakan ini akan dilaksanakan dalam dua siklus, dengan tiap siklus terdiri atas 4 tahapan yaitu: Planning (perencanaan), Action (tindakan), Observation (pengamatan), Reflection (refleksi).

Adapun jenis data yang digunakan dalam penelitian ini adalah data kualitatif dan data kuantitatif yang terdiri dari: a) Data minat belajar siswa. b) Data hasil belajar fisika siswa. Metode pengumpulan data yang digunakan dalam penelitian ini adalah angket minat belajar, dan tes hasil belajar.Instrument angket berjumlah 10 pernyataan dengan pilihan yang dibuat 4 kategori yaitu sangat setuju, setuju, cukup setuju, dan tidak setuju, skor maksimal yang dicapai oleh siswa adalah $10 \times 4=40$ dan skor minimal adalah $10 \times 1=10$. Untuk mengetahui persentasi siswa dari data angket yang diperoleh dengan menggunakan rumus porsentase. Adapun Kriteria minat siswa adalah sebagai berikut:

$$
\begin{array}{ll}
80-100 & : \text { Minat siswa sangat tinggi, } \\
66-79 & \text { : Minat siswa tinggi, } \\
56-65 & \text { : Minat siswa cukup tinggi, } \\
40-55 & \text { : Minat siswa kurang tinggi. }
\end{array}
$$


Selanjutnya data yang diperoleh dianalisis secara deskriptif kualitatif dengan menghitung ketuntasan individu dan prosentase ketuntasan klasikal. Ketuntasan belajar individu untuk mengetahui hasil belajar setiap siswa. Dengan indikator keberhasialan siswa dikatakan tuntas belajar jika siswa memperoleh nilai sesuai dengan Kriteria Ketuntasan Minimal (KKM) 70. Dikatakan tuntas secara klasikal apabila sekurang-kurangnya 85\% dari jumlah seluruh siswa di kelas tuntas.

\section{HASIL DAN PEMBAHASAN}

Di bawah ini disajikan tabel analisis angket minat belajar fisika siswa kelas XII.MIPA.3 SMA Negeri 3 Muaro Jambi;

Tabel 1. Minat siswa pada pembelajaran fisika Siswa kelas XII.MIPA.3

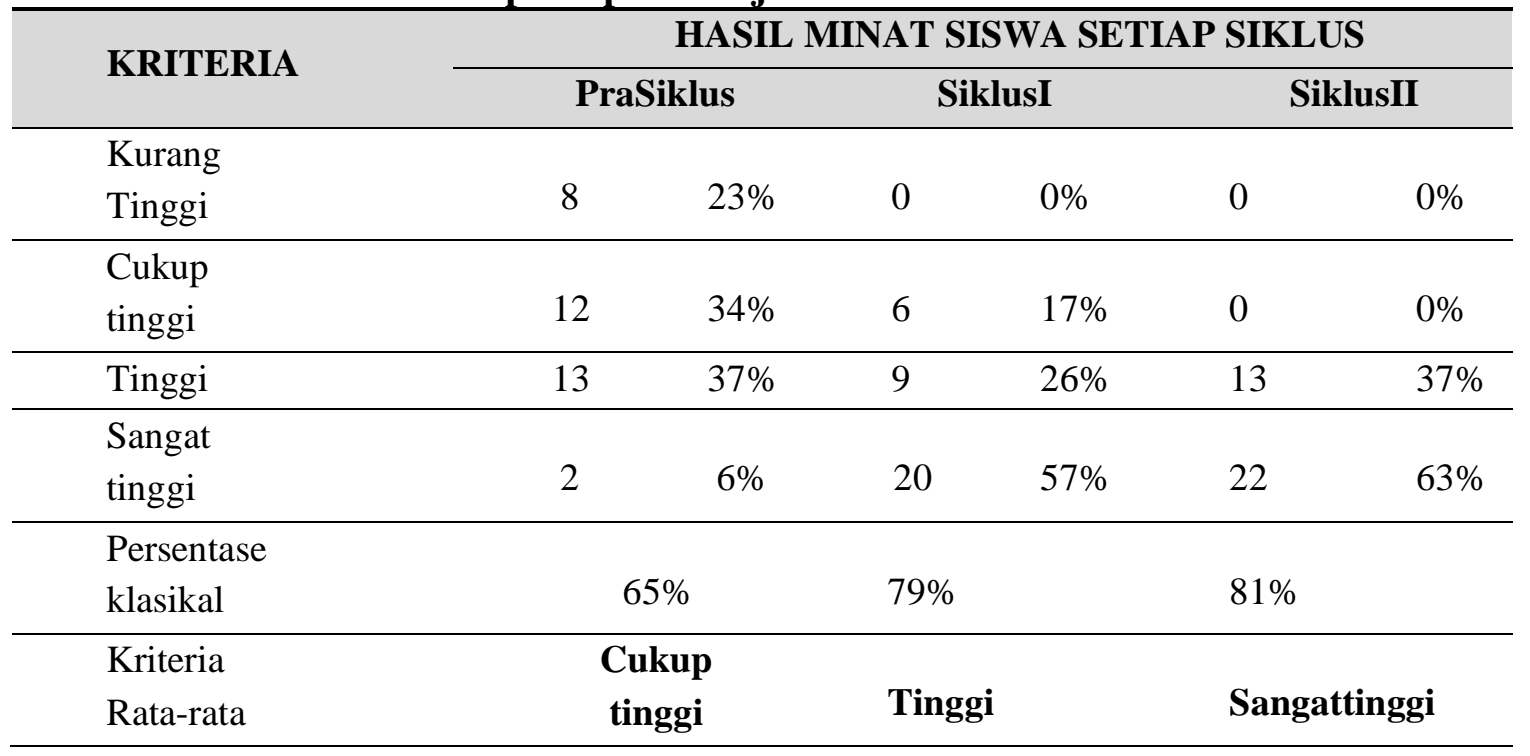

Berdasarkan data pemeriksaan jawaban siswa diperoleh hasil seperti pada tabel berikut;

Tabel 2. Hasil Belajar Siswa

\begin{tabular}{lccc}
\hline \multirow{2}{*}{ KRITERIA } & \multicolumn{3}{c}{ HASIL BELAJAR SISWA } \\
\cline { 2 - 4 } & PraSiklus & Siklus I & Siklus II \\
\hline Nilai terendah & 10 & 12 & 44 \\
\hline Nilai tertinggi & 75 & 88 & 100 \\
\hline Rata-rata & 45 & 55.1 & 81.5 \\
\hline $\begin{array}{l}\text { Siswa tidak } \\
\text { tuntas }\end{array}$ & 31 & 28 & 4 \\
\hline Siswa tuntas & 4 & 7 & 31 \\
\hline $\begin{array}{l}\text { Persentase } \\
\text { klasikal }\end{array}$ & $11 \%$ & $20 \%$ & $89 \%$ \\
\hline
\end{tabular}

\section{Pra Siklus}

Berdasarkan hasil angket pada pra siklus telah diketahui bahwa minat belajar siswa terhadap mata pelajaran fisika cukup tinggi hal ini didasarkan pada persentase klasikal mencapai $65 \%$. Dari 35 siswa, minat siswa pada kriteria kurang tinggi ada di angka $23 \%$, cukup tinggi $34 \%$, tinggi $37 \%$, dan sangat tinggi $6 \%$. Hal ini disebabkan karena pada kondisi ini pembelajaran dilakukan secara konvensional atau ceramah. Bagi siswayang kurang kreatif biasanya metode ini sangat ideal buat mereka, namun sebaliknya bagi yang kreatif metode ini 
biasanya sangat membosankan. Sehingga minat mereka berkurang buktinya dari 35 siswa yang ada hanya 2 siswa saja yang sangat tinggi minat belajar fisikanya.

Hasil ulangan dari pembelajaran sebelumnya menunjukkan bahwa rata-rata nilai fisika hanya 45 , yang mencapai nilai ketuntasan 4 siswa dan yang tidak tuntas ada 31 siswa, sehingga pada pra siklus ini persentase klasikal hanya $11 \%$. Hal ini berbanding lurus dengan minat belajar fisika. Maka upaya yang dilakukan yaitu dengan menggunakan media pembelajaran animasi 3 dimensi.

\section{Siklus I}

Berdasarkan hasil angket yang diberikan pada siswa pada setelah melakukan pembelajaran siklus I telah diketahui bahwa minat belajar siswa terhadap mata pelajaran fisika mencapai kriteria tinggi hal ini didasarkan pada persentase klasikal mencapai 79\%. Angka ini berada diantara 66-79 dengan kriteria tinggi. Dari 35 siswa, minat siswa kurang tinggi tidak ada lagi, cukup tinggi $17 \%$, tinggi $26 \%$, dan sangat tinggi 57\%. Jika dibandingkan dengan prasiklus maka minat belajar siswa terhadap mata pelajaran fisika pada siklus I terjadi peningkatan.

Hal ini dapat dilihat pada tabel minat belajar dari kriteria cukup tinggi sebelum dilakukan pendekatan pemanfaatan media pembelajaran animasi 3 dimensi meningkat pada kriteria tinggi pada siklus I. Dengan dilakukannya pendekatan pemanfaatan media pembelajaran animasi 3 dimensi maka pembelajaran tidak lagi semata-mata dari guru kesiswa atau pembelajaran didominasi oleh guru, melainkan pembelajaran didominasi oleh siswa. Artinya pembelajaran ini menuntut kreativitas dan aktivitas guru dan siswa untuk mencari literature yang berhubungan dengan konsep yang sedang mereka pelajari, peran guru hanya memfasilitasi dan memberikan penilaian terhadap hasil media tersebut.

Hasil test setelah pembelajaran pada siklus I menunjukkan bahwa rata-rata nilai fisika 55,1 , yang terdiri atas siswa tuntas 7 orang dan tidak tuntas 28 orang. Sehingga pada siklus ini persentase klasikal 20\%. Hasil ini menunjukkan bahwa ketika pembelajaran menerapkan pendekatan pemanfaatan media pembelajaran animasi 3 dimensi dapat meningkatkan hasil belajar fisika. Ketika minat belajar fisika meningkat maka hasil belajar meningkat pula.

Dari hasil yang diperoleh pada siklus I secara umum baik minat belajar maupun hasil belajar fisika pada kelas XII.MIPA.3 mengalami peningkatan. Hal ini disebabkan karena siswa aktif mencari informasi sendiri pada pembelajaran tersebut, sehingga mereka memahami materi yang dipelajari. Pada pendekatan pemanfaatan media pembelajaran animasi 3 dimensi siswa terlebih dahulu ditampilkan media pembelajaran animasi 3 dimensi pada pelajaran fisika. Dari animasi tersebut siswa diberikan pengalaman pembelajaran yang nyata dan menyenangkan agar pemahaman siswa menjadi lebih baik dan utuh.

Berdasarkan hasil refleksi dari siklus I maka pembelajaran masih perlu dilanjutkan pada siklus II, mengingat hasil siklus I belum mencapai indikator keberhasilan. Walaupun minat dan hasil belajar telah mengalami peningkatan, namun penelitian belum dianggap berhasil. Sehingga perlu dilakukan perbaikan proses pembelajaran pada siklus II.

\section{Siklus II}

Pada siklus II materi yang disampaikan adalah Fisika Inti dan Radioaktifitas. Tindakan pada siklus II tidak jauh beda dengan pembelajaran yang dilakukan pada siklus I. Sama seperti pembelajaran siklus I. Pada siklusII dilakukan sebanyak 3 kali pertemuan.

Berdasarkan hasil angket yang diberikan pada siswa pada setelah melakukan pembelajaran siklus II telah diketahui bahwa minat belajar siswa terhadap mata pelajaran fisika mencapai kriteria sangat tinggi hal ini didasarkan pada persentase klasikal mencapai $81 \%$. Angka ini berada diantara 80-100 dengan kriteria sangat tinggi. Dari 35 siswa, minat siswa kurang tinggi dan cukup tinggi tidak ada lagi, tinggi $37 \%$, dan sangat tinggi $63 \%$. Jika dibandingkan dengan siklus I maka minat belajar siswa terhadap mata pelajaran fisika pada siklus II terjadi peningkatan. Hal ini dapat dilihat pada tabel minat belajar dari kriteria tinggi pada siklus I meningkat pada kriteria sangat tinggi pada siklus II. 
Berdasarkan indicator keberhasilan penelitian dikatakan berhasil apabila criteria secara klasikal minat belajar fisika sangat tinggi, maka penelitian ini dianggap berhasil karena dengan pendekatan media pembelajaran animasi 3 dimensi dapat meningkatkan minat belajar fisika.

Hasil test setelah pembelajaran pada siklus II menunjukkan bahwa rata-rata nilai fisika mencapai 81,5 , yang terdiri atas siswa tuntas 31 orang dan tidak tuntas 4 orang. Sehingga pada siklus ini persentase ketuntasan klasikal 85\%. Hasil ini menunjukkan bahwa ketika pembelajaran menerapkan pendekatan media pembelajaran animasi 3 dimensi dapat meningkatkan hasil belajar fisika. Ketika minat belajar fisika meningkat maka hasil belajar meningkat pula.

Dari hasil yang diperoleh pada siklus I secara umum baik minat belajar maupun hasil belajar fisika pada kelas XII.MIPA.3 SMA Negeri 3 Muaro Jambi mengalami peningkatan. Hal ini disebabkan karena siswa aktif memanfaatkan media pembelajaran animasi 3 dimensi dengan belajar sendiri pada pembelajaran tersebut, sehingga mereka memahami materi yang dipelajari. Berdasarkan indikator keberhasilan diatas penelitian berhasil apabila porsentase ketuntasan secara klasikal mencapai $85 \%$. Mengingat hasil yang diperoleh pada siklus II mencapai $89 \%$ maka penelitian ini dianggap berhasil.

\section{KESIMPULAN}

Media pembelajaran animasi 3 dimensi dapat meningkatkan minat dan hasil belajar fisika pada siswa kelas XII.MIPA.3 SMA Negeri 3 Muaro Jambi, dengan capaian secara klasikal $81 \%$ untuk minat belajar pada kriteria sangat tinggi dan ketuntasan secara klasikal hasil belajar $89 \%$. Minat belajar fisika sangat tinggi dan hasil belajar meningkat dengan penggunaan media pembelajaran animasi 3 dimensi.

\section{DAFTAR PUSTAKA}

Aji, S., Hudha, M. N., \& Rismawati, A. (2017). Pengembangan modul pembelajaran fisika berbasis problem based learning untuk meningkatkan kemampuan pemecahan masalah fisika. SEJ (Science Education Journal), 1(1), 36-51.

Anggraeni, R. D., \& Kustijono, R. (2013). Pengembangan media animasi fisika pada materi cahaya dengan aplikasi flash berbasis android. Jurnal Penelitian Fisika Dan Aplikasinya (JPFA), 3(1), 11-18.

Astalini, A., Kurniawan, D. A., \& Sumaryanti, S. (2017). Sikap siswa terhadap pelajaran fisika di sman kabupaten Batanghari. JIPF (Jurnal Ilmu Pendidikan Fisika), 3(2), 59-64.

Azizah, R., Yuliati, L., \& Latifah, E. (2015). Kesulitan pemecahan masalah fisika pada siswa SMA. Jurnal penelitian fisika dan aplikasinya (JPFA), 5(2), 44-50.

Diani, R. (2016). Pengembangan modul dengan pendekatan saintifik berbasis pendidikan karakter untuk kelas X SMA/MA pada materi suhu dan kalor. In Seminar Nasional Program Studi Pendidikan Fisika.

Hudha, M. N. (2017). Authenthic Problem Based Learning (APBL) untuk Meningkatkan Kemampuan Berpikir Siswa. Jurnal Pendidikan Matematika dan IPA, 8(1), 64-70.

Kurniawati, H., Desnita, D., \& Siswoyo, S. (2016). Pengembangan media pembelajaran berbasis 3D PageFlip fisika untuk materi getaran dan gelombang bunyi. Jurnal Penelitian \& Pengembangan Pendidikan Fisika, 2(1), 97-102.

Pistanty, M. A., Sunarno, W., \& Maridi, M. (2015). Pengembangan Modul IPA Berbasis Problem Based Learning Untuk Meningkatkan Kemampuan Memecahkan Masalah Pada Materi Polusi Serta Dampaknya Pada Manusia Dan Lingkungan Siswa Kelas XI Smk Pancasila Purwodadi. Inkuiri, 4(2), 68-75.

Sujanem, R. (2012). Pengembangan modul fisika kontekstual interaktif berbasis web untuk meningkatkan pemahaman konsep dan hasil belajar fisika siswa SMA di Singaraja. Jurnal Nasional Pendidikan Teknik Informatika: JANAPATI, 1(2), 103117. 
Syahrowardi, S., \& Permana, A. H. (2016). Desain handout multimedia menggunakan 3D pageflip professional untuk media pembelajaran pada sistem android. Jurnal Penelitian \& Pengembangan Pendidikan Fisika, 2(1), 89-96.

Wiyoko, T. (2014). Pengembangan Media Pembelajaran Fisika Modul Elektronik Animasi Interaktif untuk Kelas XI SMA Ditinjau dari Motivasi Belajar Siswa.

YUDA, I. G. N. H., Suma, K., Candiasa, I. M., \& Kom, M. I. (2014). Pengembangan e-learning fisika dalam bentuk website berorientasi sains teknologi masyarakat untuk meningkatkan penguasaan konsep dan kreativitas siswa kelas XI IPA. Jurnal Pendidikan Dan Pembelajaran IPA Indonesia, 4(2). 